\title{
Troubled Pedagogies and COVID-19: Fermenting New Relationships and Practices in Early Childhood Care and Education
}

\author{
Nancy van Groll and Kathleen Kummen
}

\begin{abstract}
Nancy van Groll is an instructor in the School of Education and Childhood Studies and a pedagogist with ECEBC (Early Childhood Educators of British Columbia) living, working, and learning on the unceded lands of the selílwitulh (Tsleil-Waututh), skwxwú7mesh

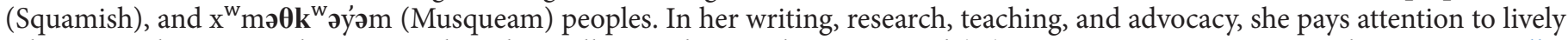
relations and activates slow, situated, and spiralling pedagogical projects with(in) $21^{\text {st }}$-century contexts. Email: nancyvangroll@ capilanou.ca
\end{abstract}

Kathleen Kummen is a codirector of the ECPN and a faculty member of the School of Education and Childhood Studies at Capilano University, located on the traditional territories of the Coast Salish peoples, including Tsleil-Waututh, Squamish, shíshálh, Lil'Wat, and Musqueam Nations. As a researcher, educator, and instructor, Kathleen endeavours to reimagine and revitalize early childhood leadership as an ongoing practice of disruption to make space for alternative narratives of early childhood education. Email: kkummen@capilanou.ca

The COVID-19 pandemic has exposed vulnerabilities, tensions, and possibilities in the Canadian early childhood education and care system. This paper experiments with the metaphor of fermentation to critically reflect on the ways we, as ECEC postsecondary instructors, were challenged in upholding our pedagogical commitments. Through retrospective analysis of emails, meeting notes, and other personal communications, we examine and describe how our work and pedagogical thinking with students has been contaminated by COVID-19. We highlight the need to refigure relationships to the troubling events and reconceptualize contamination as a potent opportunity to pedagogically ferment practices in the postsecondary classroom through which living and learning well can flourish.

Key words: early childhood education; early childhood teacher education; pedagogical practice; COVID-19

Worlds Research Collective, 2020; Early Childhood Pedagogies Collaboratory, 2021; Nxumalo, 2019; PaciniKetchabaw et al., 2015; Vintimilla \& Pacini-Ketchabaw, 2020).

We, Nancy and Kathleen, are instructors in an early childhood education program at a small university in British Columbia (BC) with campuses located on the territories of the Lílwat (Lil'wat), $\mathrm{x}^{\mathrm{w}} \mathrm{m} ə \theta \mathrm{k}^{\mathrm{w}} \partial y$ 'əm (Musqueam), of the Canadian early years landscape (see, e.g., Friendly et al., 2020). Through this exposure and combined with the 2021 federal budget announcement of funding for a national childcare plan (Government of Canada, 2021), attention has been renewed to the role of early childhood education and care (ECEC) as the media, government, academics, and other groups present competing narratives of ECEC. For example, ECEC touted as a redemptive service to the economic woes brought on by COVID-19 (Government of Canada, 2021) bumps up against assertions by scholars such as those in the Early Childhood Pedagogies Collaboratory (2020) that early childhood education is a pedagogical project with potential for social change. Each of these discourses could decisively influence the life of children, families, educators, and communities in very different ways. Equally, each of these narratives will shape the education of future early childhood educators. Within a service model, postsecondary institutions are positioned as training programs producing the necessary workers to ensure available care for the children of the workforce. In contrast, within a pedagogical project, future educators require an education that supports them to think and engage in pedagogical practices that respond to the complexity and challenges of the $21^{\text {st }}$ century (Common

The COVID-19 crisis has exposed the troubling fragility 
shíshálh (Sechelt), sǩwwxwú7mesh (Squamish), and selílwitulh (Tsleil-Waututh) Nations (now geographically referred to within BC as the Lower Mainland comprising Vancouver, the Sunshine Coast, and the Sea-to-Sky Corridor). As instructors working within a postsecondary ECEC program in BC, we take seriously the BC Early Learning Framework's (2019) vision that early childhood educators cocreate pedagogical spaces so that we can ethically live and learn well together. The framework is a localized curriculum document that establishes a shared vision for ECEC in the province and creates a point of dialogue for early childhood educators, teachers and administrators in the primary school system, university instructors and researchers, postsecondary students in early childhood and elementary education programs, and other interdisciplinary professionals (Government of British Columbia, 2019). We, as do our colleagues across BC, strive to provide our students with opportunities to develop the dispositions to engage in pedagogical practices that support this vision as we respond to the current conditions of our time.

As we supported early childhood educator candidates through the pandemic, we noticed and became increasingly concerned by what we perceive to be a collision between our pedagogical orientations and commitments and the need to "produce" early childhood educators. In the context of recent federal and provincial investments into early childhood education (Government of Canada, 2021), we became aware of a mounting pressure for postsecondary institutions to respond to the documented shortage of early childhood educators in BC (Coalition of Childcare Advocates of BC \& Early Childhood Educators of British Columbia, 2020). At the same time, COVID-19 presented postsecondary programs with additional, unforeseen challenges that require continual negotiation to respond in ways that support student learning.

Partway through the Spring term of 2020, most early childhood programs were closed in BC, and many early childhood education students had their practicum interrupted or postponed. The disruption in practicum resulted in a delay in graduation for some students, and for others, an extension of their program length. In the preceding terms (Summer 2020, Fall 2020, and Spring 2021), practicum placements were tenuous as some centres chose not to host practicum students to reduce the spread of COVID-19. This meant that many students were unable to complete their practicum because they were not able to be present in an early childhood centre in compliance with the requirements the Early Childhood Educator (ECE) Registry, the licensing body for early childhood educators in BC. Working with the ECE Registry, our program, alongside other programs in BC, was able to secure practicum sites for a few students, but many students' ability to complete a practicum was disrupted. Further, our university, like other postsecondary institutions in the province, moved classes online. This change required both students and instructors to adjust as we negotiated the curriculum in an online format. COVID-19 created conditions for learning that were unprecedented in our teaching lifetimes and asked us to think imaginatively to create supportive pedagogical spaces for future early childhood educators. The pandemic reinforced the need for us to expect the unexpected, a necessary condition for teaching according to our former colleague the pedagogist Cristina Delgado Vintimilla (personal conversation, 2011).

Our experiences of transitioning our classes online and supporting students in practicum and coursework illuminate the ways in which our particular pedagogical commitments were challenged in our responses to COVID-19. Responding to the virus's emerging narratives pushes us to question how we got here and what our response-abilities (Haraway, 2016) are as ECEC instructors living with(in) a pandemic. Can we begin to consider what we might leave behind as we imagine the transformative possibilities COVID-19 has exposed?

This paper is a retrospective analysis of the tensions, struggles, and ethical dilemmas we encountered as postsecondary instructors as we navigated unfamiliar challenges and conditions created by COVID-19, documented in our notes taken in department meetings, email exchanges, and personal conversations. Many times, as restrictions were 
imposed to reduce the spread of the virus, we encountered moments where we were compelled to ask questions about our practices as instructors. For example, is it possible for students to learn to live well with children when early childhood centres are closed or not available to host practicum students? What is our responsibility to students who have invested time and money into their education when a pandemic disrupts it? Each of these incidents were met by instructors carefully and thoughtfully considering the context and complexity of the situation in order to make an ethical decision. Yet, as we move toward the end (we hope) of restrictions and as students return once more to campuses and early childhood centres, we as educators are compelled to critically reflect on the incidents and academic decisions that emerged in response to COVID-19. We were provoked by Alexis Shotwell (2020), who asks: What relationships do we want to grow out of this crisis? This question is particularly pertinent as BC and other provinces enter new phases in public health "reopening" plans and instructors envision how they will return to campus with students. Do we want to return to a pre-COVID world? Or might we instead pause with this question to consider the opportunities COVID-19 has made visible that offer possibilities to imagine new narratives for the education of future educators?

To help us answer Shotwell's question, we propose thinking with and pedagogically experimenting with the metaphor of fermentation and its processes of contamination, collaboration, and transformation to ground ourselves in our pedagogical values as we embrace uncertainty and envision possible futures for our field. Throughout this paper, we think with feminist, posthumanist scholars such as Donna Haraway and Anna Tsing to answer Shotwell's question in the context of our practice as educators of future educators. Our intention is to make visible some of the dominant discourses and narratives about early childhood education at the postsecondary level that we encountered as instructors during the pandemic. The purpose is not to critique responses that were made, but to make visible and contest hegemonic discourses (Moss, 2019). Our hope is that this paper will activate dialogue in and beyond the postsecondary classroom as we consider the learning offered by our exposure to COVID-19. To make space for alternative narratives and new possibilities in early childhood education, we must first make visible the discourses that regulate our practice so that they can be disrupted and contested (St. Pierre, 2000).

Fermentation, from a microbial perspective, is a slow process of cellular metabolism whereby microorganisms digest and transform micronutrients (Katz, 2020). Fermentation involves contamination, collaboration, and transformation - the breakdown of previous forms into new forms. Drawing from Sandor Katz (2020), we see fermentation as a metaphor that can help us deeply consider Shotwell's question. Katz contrasts fermentation with fire, another process of biological transformation, and maintains that where fire destroys, sometimes unpredictably and uncontrollably, fermentation can slowly and steadily initiate something new. Fermentation can be seen as a form of activism that allows us to "stay with the trouble" (Haraway, 2016) and make intentional decisions about what ideas, practices, or values we would like to cultivate, or contest and leave behind.

What follows is a conceptual exploration of our relationships to COVID-19 through the metaphorical processes of contamination, collaboration, and transformation. We begin by thinking about how we have been contaminated by the virus: how COVID-19 exposed certain narratives, conditions, and discourses that challenged or transformed our pedagogical commitments. Next, we consider the possibilities of reframing our relationship with the virus from one of controlling to one of collaborating with or living well with COVID-19. Finally, we discuss how relating to the virus (and to troubling conditions in general) has generative potential to activate alternative narratives and ways of being in early childhood education and care.

\section{Contamination: Responding to COVID-19}

Shotwell (2020) states that, in our attempt to control the spread of COVID-19, we have created practices to contain 
our relationships to the virus, from shutting borders, to shuttering businesses, to physically distancing from others. Such practices reflect a belief, according to Shotwell, that our bodies have boundaries that can be shut down to prevent invasion by viruses and bacteria. We engage in activities designed to protect individuals from being touched or contaminated by perceived harmful microorganisms. In an increasingly sanitized Western society, the word contaminate conjures up fear, anxiety, and the need to seek protection. Interestingly, "contaminate" comes from the Latin word contaminatus, meaning to corrupt or defile. When viruses and bacteria become contagion, they are seen as corrupting, through touch and contact, what was pure. Shotwell (2016) reminds us that we have never been pure and there was never a time when our bodies did not share the toxins of the environment. She argues that the human condition is one in which we are "co-constituted with the world, ontologically inseparable" (p. 7) from that which we see as contaminating us. In this way, we are actively engaged in relations as co-inhabitants of worlds populated by humans, plants, animals, bacteria, viruses, fungi, and other organisms that live upon and within us. Microbially, interspecies contact and the resulting "contamination" is not only inevitable but an essential aspect of our world making. As humans we are always contaminating and being contaminated in our encounters with the world. Our relationships to the COVID-19 virus are no exception. Our ethical response-ability as educators is to consider which relationships we want to maintain and what discourses we want to disrupt in order to create conditions for living and learning well to flourish.

In reflecting on the past academic term at our own university as well as on information gleaned from other institutions either through personal conversation, meetings, or the media, we now wonder if an opportunity was missed to invite students and faculty to attend to the complicated relationships and consequences emerging from living with COVID-19. From the privileged position of hindsight, it could be argued that we were trying to retain a sense of normalcy that worked to erase the realities of the pandemic. This article is not offering a critique of these acts and other program responses that were enacted to maintain the flow of education. Rather, the intention is to engage in a critically reflective analysis to consider the discourses that necessitated the desire to maintain normalcy as opposed to responding differently. This retrospective analysis requires asking difficult questions in order to unpack decisions made during the pandemic. However, the point is not to then appraise our actions or those of others as "good" or "bad" but to consider the discourses that regulate all of us in postsecondary education. To wonder if the discourses of efficiency and production meant that we unintentionally positioned early childhood programs as services for students to complete a practicum and our job as focusing on locating practicum sites. To consider if we inadvertently became sites of production as opposed to pedagogical spaces. To ask if we were strengthening our relationships with managerial logics as a way to negotiate the disruptions to-and, as a result, inadvertently driving wedges into-our pedagogical commitments.

Our lived experiences as educators of future educators have exposed us to and made visible the way educational discourse challenges or transforms our pedagogical commitments. For example, many students' practicum placements suddenly ended when early childhood programs temporarily closed multiple times as the virus moved in and out of communities. A report by the Childcare Resource and Research Unit in June 2020 noted that $71 \%$ of Canadian early years programs closed in the pandemic's initial months (Friendly et al., 2020). As early childhood education centres began to reopen, heightened concerns around communicable disease control meant that educators adopted disease containment practices, which reduced the presence not only of families but also of practicum students. As instructors of early childhood educators, it was not difficult to get caught up in the desire to rush to find a fix for the emerging challenges and to plan for the resumption of the "pre-crisis production model" (Latour, 2020) of an efficient postsecondary program. As is evident in a review of student emails, meeting notes, and personal communications, our schedules became overwhelmed from meetings with students and colleagues to deal with the ongoing difficulties of practicum disruptions as students were required to self-isolate in response to their own exposures to COVID-19. The disruption to studies meant anxieties were heightened as 
COVID-19 restrictions jeopardized planned graduations. The need to maintain the production of early childhood education graduates threatened to become the dominant narrative in our postsecondary institution. As neoliberal subjects, we struggled to "do a good job" to graduate students to meet market demand. Doing so created ethical and pedagogical tensions as we worked to "fix" the problems.

Shotwell's (2020) invitation to consider COVID-19 as a relationship in order to invite "ethical, political, and ecological evaluations of the relationships we proliferate in response to 'the virus"' (para. 1) offers us a way to move beyond only a commitment to produce graduates. She suggests attending to the narratives and practices being produced with and in our relationships with the virus. By identifying what has emerged in response to the virus, we can then ask ourselves, are these the practices and stories that we want to flourish in early childhood education? For example, the hegemonic discourse of early childhood education as a service has been strengthened through the relationship emerging between COVID-19 and the economy. This service narrative, Peter Moss (2019) contends, positions early childhood education as a commodity whose purpose is to provide safe care for children while their parents work. In this narrative, educators are entrepreneurs and parents are consumers purchasing a service that meets their individual needs. Moss argues that this discourse reduces early childhood education to a competitive service where consumers aim to purchase the best quality at the lowest price. Thinking with Moss's argument, it could be asserted that if the COVID-19/economy alliance is left to flourish in early childhood education, it reduces the possibility of considering alternatives beyond the market economy. If we want to disrupt early childhood education as a service, then we need to attend to alternative relationships emerging within the pandemic that are not found in the marketplace. Specifically, we must consider generative relationships that respond to this pandemic in ways that offer possibilities to live and learn well together.

We know that to challenge the singular service narrative of COVID-19 will require a deep consideration of the relationships that exist in the conditions of our time. To help us in this task, we think with Donna Haraway (2016), who invites us to stay with the trouble. What will emerge if we stay with a relationship to COVID-19 given that it appears that COVID-19 is with us even with vaccines? What is possible if we allow education to stumble alongside a pandemic rather than move it forward in spite of the pandemic? Shotwell (2020) contends that "the relations we create out of [this] pandemic will determine who lives and who dies" (para. 6). We extend her argument to early childhood education, a political project that produces future citizens (Moss, 2019). Therefore, we argue that the relationships that emerge from COVID-19 within early childhood education can determine the type of humans who will live in post-COVID-19 worlds. Shotwell asks us to make choices that involve collective care and resist oppression. This paper will argue that we need, as educators, to make choices that involve commitments to collaborative learning and pedagogies that vigorously resist competition and individualism. Our concern in the education of early childhood educators is: How do we invite students to expect teaching (and perhaps life) to be what Alecia Jackson (2001) describes as a "wrenching, uneven experience" (p. 388)? As teachers of early childhood educators, we need to create learning spaces that explore what it means to teach, live, and practice in unstable, unpredictable, always emerging worlds that include contagion.

In the next section of the paper, we move from the contamination stage of fermentation to collaboration. Here, we continue to think with Haraway's (2016) notion of staying with the trouble and introduce Anna Tsing's (2015) concept of contamination as a livable collaboration. When contamination is understood as inevitable and generative, space opens up to invite future educators to consider what happens when ideas, curiosities, and thoughts are allowed to contaminate each other. New questions emerge, such as, what can we learn from contagion in order to create postsecondary spaces where contamination is a desirable event? 


\section{Collaboration: Pedagogies that stay with the trouble}

Haraway (2016) reminds us that we live in beautiful, disturbing, and mixed-up times that overflow with both pain and joy. She understands that to stay with the trouble is a potent response that resists the "vanishing pivot between awful or edenic pasts and apocalyptic or salvific futures" (p. 1). Pedagogies of staying with the trouble of a pandemic bring attention to the narrative of what is and what might be possible in education. As we encountered and responded to each unfolding and at times escalating condition of COVID-19, we found ourselves looking for what Haraway terms a technofix - that is, an attempt to erase the trouble in order to move forward as if the pandemic were not living in the world. Without a visible technofix, such as a vaccine, we wondered if we should pause until we returned to the pre-crisis production model of early childhood teacher education (Latour, 2020). For example, when the university closed at the beginning of the pandemic, we immediately moved all our face-to-face classes online. Within three days, instructors transformed their curriculum so that the production of graduates would not be interrupted by COVID-19.

There was a heightened frenzy focused on maintaining activities as if the pandemic were not a reality. It was as if we were trying to maintain a neutral equilibrium in which learning and pedagogy were outside of the unfolding troubles. It was as if illness, death, and fear were not part of curriculum planning nor considered in the speed with which we transitioned to the online platform. This is another example of Haraway's technofix-our production of graduates was rescued by educational technology platforms. This is not to say that this decision and the speed at which these activities occurred were wrong, but rather to pause and consider what was lost in our need to "fix" things immediately. By not acknowledging our relationship with COVID-19, is it possible that what students saw was that educators were working to maintain the status quo and not to pedagogically respond to the conditions of the time. Assignment expectations and readings were unchanged as online lectures were conducted without accommodation to the virtual environment. In reflection, did we inadvertently create conditions where students learned that curriculum and learning occur outside of the world rather than as a part of it? Had we reinforced a belief that planned activities must go forward in spite of, and not in response to, the worldly conditions?

This scenario brought to mind an image of the first snowfall in coastal BC (a rare event in a temperate rainforest) and children being kept inside by an enthusiastic practicum student to complete what had been planned the night before. In teaching students to avoid the unexpected or unpredictable, we maintained neoliberal discourses of efficiency over living. It could be argued that we avoided pedagogies that invited both students and instructors to ponder how to live and learn with COVID-19. How then could we expect students to imagine pedagogies that are slow and responsive and thereby attentive to both the pain and joy that are life and learning?

If we work to stay with the trouble of what is occurring in our world, we are required then to pause, acknowledge, and respond to the conditions we are facing. This requires a time of critical reflection to consider what has been lost in order to reconfigure our practices to meet new demands. Haraway (2016) refers to this time of attending to loss as a mourning that opens us to become aware of our relationships and our dependency on them. If we take seriously Shotwell's invitation to attend to the relationships lost through COVID-19, a period of mourning is necessary to evaluate what we want to leave behind and what we want to move forward into the new worlds we are meeting. When we pause to mourn what existed in early childhood before COVID-19, we allow ourselves time to critically examine the relationships of the past. Take, for example, the ritual and routine of drop-off and pickup in early childhood centres. Many of our students, as well as other educators we talked with during this time, mourned the loss of this ritual. They explained that this time of day was essential to nurture relationships between families and educators. However, it was through the opportunity to mourn the loss of this routine as a result of COVID-19 that we were able to discern whether or not this practice was producing the desired relationships between educators and families. Was the practice allowing our pedagogical commitment to relationships to 
flourish? Were we mourning something real or something we imagined or assumed to be there? We can open up to the possibility that the simple exchange of niceties and information about a child's day is not always the most generative or the only way to nurture a relationship. Were those moments of greeting more of an efficient routine for exchanging information perceived as important? Was it possible that we were confining a whole relationship to the drop-off and pick-up routine? As our province moves into the next stage of easing restrictions, should we be inviting our students into this critical dialogue? We have an opportunity to generate possibilities for examining what practices allow relationships to flourish in multiple, lively ways that are not confined to particular times or places. The reader should note we are thinking with Foucault (1983). That is, we are not suggesting that drop-off times are good or bad, but rather that all practices have potential to support or hinder relationships.

Staying with the trouble of COVID-19 in early childhood education allows us to ask different pedagogical questions and ethically attune to local, situated, and unique needs. We are able to ask which relationships, narratives, and practices we want to flourish and what we want to leave behind. Pedagogies that stay with the trouble can be a way to enact what Isabelle Stengers (2020) terms generative interdependence, or actively letting oneself be moved, affected, troubled, intrigued, or involved with an idea, a body, a virus, a relationship, and so on. A generative interdependence with COVID-19 means not passively being affected by the virus and accompanying conditions; instead, it requires an active and intentional way of being so that alternative narratives can flourish. Staying with the trouble in postsecondary early childhood classrooms evokes the possibility to focus on ethical relationships and encourage students to ask pedagogical questions of how to live well together. Pedagogies of staying with the trouble of COVID-19 might, as Shotwell (2016) suggests, "hold the possibility of another world, still imperfect and impure, and another one after that" (p. 214).

Anna Tsing (2015) sees contamination as a generative process of livable collaborations—the meeting across differences to refigure our relationships and encounters to activate and form something new. To be in a livable collaboration with COVID-19 is to stay with the tension of the unknown and to actively be moved by uncertainty and the unpredictable nature of life. The world is not neutral; COVID-19 is not the only challenging condition we face. Relationships are always contradictory and can always be dangerous. To be in a livable collaboration with this virus is to attend to the messy, complicated relationships it exposes and to intentionally avoid romanticizing the past or the future.

In our thinking about our pedagogical relations with COVID-19, we wonder what might happen if we reject narratives of purity and embrace the concept of contamination differently. Thinking from a posthumanist perspective, COVID-19 has contaminated the way we touch, the way we live, and the way we relate. We respond to the touch of COVID-19 with the ways the virus encounters our bodies and our minds: We talk about it, fear it, avoid it, carry it in our bodies as we try not to breathe it in. Our students encountered contamination literally and metaphorically as they resumed practicum experiences in the fall. There was struggle and friction as we reduced the number of students placed in centres in an effort to contain the virus. To reduce the number of adults in a classroom, we moved away from our practice of placing two practicum students together in a classroom. Yet, we did not consider how the containment of students might impact their learning as future educators. Focused, and rightly so, on planking the COVID-19 curve through managerial logics, we did not pause to reimagine how we could continue to bring students together to engage in the coconstruction of curriculum. The rush to ensure practicum placements, maintaining graduation rates, overpowered our commitment to collaborative learning. It is important to note that we are not questioning the decision to reduce the number of students in a classroom; we are interrogating our failure to seek alternative ways to create the conditions for collaboration. Our relationship with pedagogy was being threatened by our relationship with production. 
As instructors we are inspired by scholars such as Hillevi Lenz Taguchi (2009), who asserts that diversity of groups makes for richer knowledge. If students are able to be contaminated by one another's ideas, values, or philosophical orientations, different pedagogical possibilities might be activated than when they learn in isolation. When we work against containment in our pedagogical work with students, we are able to support them to seek opportunities to contaminate, be contaminated, and respond to those encounters in ethical ways. This is not to suggest that we were wrong in working to reduce the spread of COVID-19, but we should have continued to create opportunities for ideas to be contaminated. Contamination of a virus could have become a discourse that generated alternative pedagogies, pedagogies that contained a virus while opening up spaces for pedagogies of contamination.

In our critical reflections, thinking with Shotwell and Haraway, we recognized that COVID-19 was not a part of the cocreation of curriculum other than to contain its spread. Lenz Taguchi (2009) talks about materials as agentic in curriculum making, in which their presence or absence matters in what is pedagogically possible. In classrooms where COVID-19 was an active material presence beyond containment, children were curious about its invisibility, about contamination, about touch, and about how the virus moved and lived. When the virus was acknowledged as a relevant part of children's lives, curriculum was constructed with children and educators to explore their concerns, curiosities, and even fears. Unfortunately, we could see as instructors that we were pulled into the neoliberal agenda of maintaining neutrality and the status quo. Had we paused and thought more deeply with our students and our pedagogical commitments, we could have supported more of our students in reimagining responsive curriculum in a pandemic_curriculum in which COVID-19 was agentic matter to think with, not simply to contain.

\section{Transformation: Activating new relationships}

Taking up the concept of fermentation in education makes space for pedagogical events as encounters and enlivens transformative possibilities. The effervescence of fermentation in the context of ECEC invites into educators' pedagogical work the fermenting of experimentation, democracy, and diversity while refiguring a sustainable collective life. By attuning to the way ideas, encounters, and ways of being unfold, bubble, transform, and are reinvented, we stay with the terrestrial troubles of living well together in a pandemic and resist searching for neoliberal fixes or endings. Thinking about our relationships with COVID-19 through the lens of fermentation is generative in that it not only allows us to think critically about what has troubled us, or how we have been contaminated, but also invites us to deliberately activate something new. Staying with the trouble, and mourning, are necessary processes to move toward fermentation, as a state of intentional activation, the process of making choices about the relationships, values, or ideas that contaminate us and our practices and create conditions in which we can generate spaces of activism that ethically reconfigure or transform the status quo. To discern what practices reflect certain ethical, political, or pedagogical commitments is particularly important to the process of fermentation, because not everything can or should ferment. Educators must recognize what discourses are swirling in the formation that will be produced as a result of these choices or practices. Shotwell's provocation is helpful for us in this process as we choose carefully what pedagogical practices we wish to let go of and what we wish to move forward in our ongoing relationship with a pandemic and other messy, difficult parts of life.

In returning to the examples presented throughout this paper, COVID-19 exposed many situations in which, had we as instructors made intentional choices about the ways our practices and values fermented, something new might have been activated that held transformative possibilities for our students. The aforementioned fixing, containing, and sanitizing that we gravitated toward as instructors did not create opportunities for activism or the fermentation of our response(ability) to the ethical, political, and pedagogical conditions that arose. However, it is our hope that this paper might act as a form of pedagogical fermentation in the way we have presented and 
critiqued our own experiences for the purpose of activating alternative narratives, discourses, and practices. Life and education will always be troubled and full of friction, loss, and uncertainty, but the way we refigure our relationships to the conditions we meet positions us to respond differently and to coconstruct more livable worlds.

As the rate of vaccination increases, the question of which ideas or values we bring forward to ferment and which ideas or values we leave behind is essential. Ethical questions about individual purity will begin to contaminate our work, and we will be asked to stay with different kinds of trouble. We as instructors will inevitably be met with moments of challenge, but the way we create conditions for students to cultivate pedagogical fermentation opens up a disposition of what Shotwell (2015) refers to as "flourishing, toward the contingent proliferation of ways of being we cannot predict, toward surprise” (p. 102). In repositioning the ways we encounter future surprises and unpredictability through the lens of relationships, we can be thoughtful and intentional about the narratives and practices that are produced. By allowing pedagogies informed by fermentation, we are more likely to be response(able) to ferment ideas and processes that cultivate practices that do not unintentionally return to discourses unable to sustain our political and ethical orientations.

Resisting and disrupting narratives that position ECEC as a commodity or COVID-19 as a troubling condition that can be overcome through a technofix requires an attunement to the relationships that might already align with pedagogical fermentation. It is our intention that the conceptual ideas presented in this paper might reground us within existing local and situated professional initiatives that orient us toward contamination, fermentation, and flourishing. For example, Kummen and Hodgins (2019) discuss the ways in which the Investigating Quality (IQ) Project presented generative possibilities that arise out of establishing and encouraging learning collectives that include postsecondary instructors, students, and community-based educators. This project articulates the ways ECEC instructors, students, educators, and other community members can collectively reorient themselves to be authentic by upholding their values and pedagogical commitments. The resulting advocacy for creating a "collective culture of ECEC" generated possibility for cultivating spaces that enable and encourage a contamination of ideas.

Fermentation as a metaphor has helped us reexamine and contest our experiences as postsecondary instructors during the initial waves of COVID-19 in BC. As we have seen throughout this paper, COVID-19 contaminated the ways we responded to and with our students. It created conditions, we assert, that might have been generative to learn from or be in a livable collaboration with, rather than simply work to fix or resolve. However, through this retrospective analysis, we are able to identify transformative possibilities for responding differently to troubled conditions in the future. Through this conceptual experiment, we situate ourselves within the understanding that we have been forever contaminated by COVID-19 and will continue to be tainted by troubles we have not yet encountered. Looking at COVID-19 through the metaphor of fermentation helps us see the inevitability of transformation that comes out of being troubled by viruses, events, or hegemonic discourses. It also supports us to actively resist romanticizing what Haraway (2016) refers to as the edenic past and salvific (or apocalyptic) future.

Fermenting troubled pedagogies with our postsecondary students realigns us with our pedagogical commitments and reorients us to our response(ability) to the political and ethical values we espouse. This process is essential given federal and provincial investments in early childhood education and care, which, when contaminated by particular narratives or ideals, will ultimately ferment into new realities for children, families, early childhood educators, future early childhood educators, and communities. What we want to teach our students is that relationships to trouble are at the heart of the educational project. Our goal should be to create curriculum in the postsecondary classroom that is always in relationship to the complex and ever-changing conditions of our times. This requires postsecondary instructors to continually engage in the pedagogical process of asking ourselves and our students what relationships we want to ferment in early childhood education. By asking these questions and 
acknowledging our generative interdependence on troubles and unknowable futures, we begin to speculate about and activate alternative narratives that have been contaminated by livable collaborations with COVID-19.

We hope the legacy of COVID-19 is one that encourages our students to stumble alongside troubles, to activate the possibility that pedagogies can ferment flourishing alternative responses of living well together. This possibility requires us to consistently resist the allure of Haraway's (2016) technofix so as not to activate Latour's (2020) precrisis production model when we encounter trouble. As postsecondary instructors, we need to take from our lived experiences with COVID-19 the importance and the challenges of privileging pedagogy over discourses of efficiency and managerial logics. 


\section{References}

Coalition of Childcare Advocates of BC \& Early Childhood Educators of British Columbia. (2020). Next step: A competitive, publicly funded provincial wage grid is the solution to BC's ECE shortage. https://ecebc.ca/application/files/4915/9553/5275/CCCABC ECEBC Wage Grid Report June 2020 web.pdf

Common Worlds Research Collective. (2021). Website. https://commonworlds.net/

Early Childhood Pedagogies Collaboratory. (2020). Conditions for moving beyond "Quality" in Canadian early childhood education: An occasional paper. Childcare Resource and Research Unit. https://childcarecanada.org/documents/research-policypractice/20/12/conditions-moving-beyond-\%E2\%80\%9Cquality\%E2\%80\%9D-canadian-early-childhood

Early Childhood Pedagogies Collaboratory (2021). Website. https://www.earlychildhoodcollaboratory.net/

Foucault, M. (1983). The subject and power. Afterword, in H. L. Dreyfus \& P. Rabinow (Eds.), Michel Foucault: Beyond structuralism and hermeneutics ( $2^{\text {nd }}$ ed.; pp. 208-226). University of Chicago Press.

Friendly, M., Forer, B., Vickerson, R., \& Mohamed, S. (2020). Canadian child care: Preliminary results from a national survey during the COVID-19 pandemic. Childcare Resource and Research Unit. https://childcarecanada.org/sites/default/files/Canadian-ChildCare- COVID19-Survey-Data-Report.pdf

Government of British Columbia. (2019). BC early learning framework. https://www2.gov.bc.ca/gov/content/education-training/earlylearning/teach/early-learning-framework

Government of Canada. (2021). Budget 2021: A Canada-wide early learning and childcare plan. https://www.canada.ca/en/departmentfinance/news/2021/04/budget-2021-a-canada-wide-early-learning-and-child-care-plan.html

Haraway, D. J. (2016). Staying with the trouble: Making kin in the Chthulucene. Duke University Press.

Jackson, A. Y. (2001). Multiple Annies: Feminist poststructural theory and the making of a teacher. Journal of Teacher Education, 52(5), 386-397. https://doi.org/10.1177\%2F0022487101052005005

Katz, S. E. (2020). Fermentation as metaphor. Chelsea Green.

Kummen, K., \& Hodgins, B. D. (2019). Learning collectives with/in sites of practice: Beyond training and professional development. Journal of Childhood Studies, 44(1), 111-122. https://doi.org/10.18357/jcs.v44i1.18785

Latour, B. (2020, March 29). What protective measures can you think of so we don't go back to the pre-crisis production model? (Originally published, in French, in AOC). http://www.bruno-latour.fr/sites/default/files/downloads/P-202-AOC-ENGLISH 1.pdf

Lenz Taguchi, H. (2009). Going beyond the theory/practice divide in early childhood education: Introducing an intra-active pedagogy. Routledge.

Moss, P. (2014). Transformative change and real utopias in early childhood education. Routledge.

Moss, P. (2019). Alternative narratives in early childhood education: An introduction for students and practitioners. Routledge.

Nxumalo, F. (2019). Decolonizing place in early childhood education. Routledge.

Pacini-Ketchabaw, V., Nxumalo, F., \& Kocher, L., Elliot, E., \& Sanchez, A. (2015). Journeys: Reconceptualizing early childhood practices through pedagogical narration. University of Toronto Press.

Shotwell, A. (2016). Against purity: Living ethically in compromised times. University of Minnesota Press.

Shotwell, A. (2020, May 7). Containment vs. care. https://alexisshotwell.com/2020/05/07/containment-vs-care/

Stengers, I. (2020). The earth itself won't let it be watched. In B. Latour \& P. Weibel (Eds.), Critical zones: The science and politics of landing on Earth (pp. 228-235). ZKM | Center for Art and Media Karlsruhe \& The MIT Press.

St. Pierre, E. A. (2000). Poststructural feminism in education: An overview. Qualitative Studies in Education, 13(5), 477-515. https://doi. 
$\underline{\operatorname{org} / 10.1080 / 09518390050156422}$

Tsing, A. (2015). The mushroom at the end of the world: On the possibility of life in capitalist ruins. Princeton University Press.

Vintimilla, C. D., \& Pacini-Ketchabaw, V. (2020). Developmentalism and pedagogy: Opening horizons in early childhood education. European Early Childhood Education and Research, 28(5), 628-641. 